\title{
The Effects of Multimedia Computer- Assisted Instruction on Learning Basic Ballet Skills with Physical Education Students
}

Authors' contribution:

A) conception and design of the study

B) acquisition of data

C) analysis and interpretation of data

D) manuscript preparation

E) obtaining funding

\author{
Doaa Abd El-Moneim \\ Zagazig University, Egypt
}

ABSTRACT

Computer technology has become an integral part of physical education, yet there have been few studies exploring the use of multimedia technology in the instruction of Physical Education. The purpose of this study was to investigate if multimedia technology affected the learning of basic ballet skills. A total of 32 female students, mean age 18.1 years, studying at the Faculty of Physical Education Zagazig university were divided into two groups. The experimental group comprised 16 students. Participants in this group participated in a ballet class with multimedia technology for six weeks. Group two participated in the ballet class with the traditional method as the control group. Parameters assessed height, weight, age, and academic level. All participants were free of any disorders known to affect performance, such as bone fractures, osteoporosis, diabetes, or cardiovascular disease. Participants reported no use of anti-seizure drugs or alcohol. In addition, all participants were fully informed of the aims of the study, and gave their voluntary consent prior to participation. The measurement procedures were in accordance with ethical human experimentation. All statistical analyses were calculated with the SPSS statistical package. Results indicated significant differences between the two groups in learning the basic skills and levels of knowledge of ballet. Applying the proposed educational program meant using multimedia to teach basic ballet skills to second-year female students enrolled in the Faculty of Physical Education.

KEYWORDS learning basic, ballet skills, physical education, multimedia computer

\section{Introduction}

Traditional academia confirmed their educational methods in that the teacher was the primary source of knowledge and working actor, and was the bedrock of the education process. This totally neglected the role of the learner. With this came the foundation of the modern view of education. In recent years, 
information technology has been integrated into teacher education courses in many ways, including CDROMs, interactive videodiscs, teleconferencing, electronic mail, and microcomputers with hypermedia/multimedia programs. Computer-assisted Instruction (CAI) is just one of these technological applications.

Technology in the information revolution has provided unique benefits to instructional programs. Although traditional ways of instruction are widely accepted in teaching and learning environments, some educational institutions have started to implement computer technology as an instructional approach (Bull et al., 1989, 1991; Harris \& Anderson, 1991; McKethan et al., 2001; Wagonner, 1992; Wilkinson et al., 1999). The educational situations must be equipped with the means to facilitate both the acquisition of information and the speed of learning at the same time. This then distinguishes today's teacher from traditional teachers: the ability to diversify the use of teaching aids.

Multimedia technology as an advanced technology in audio-visual education programs is applied more and more widely with the advancement of times and the development of science and technology, such as in a college physical education.

CAI has been used for more than five decades for educational purposes. Although the use of computers is not new, CAI is still a popular. It is a common term in today's educational institutions and schooling process. CAI provides an instructional interaction between the learner and the computer in a variety of contexts with or without the assistance of a teacher (Lockard \& Many, 1997).

Effective study of the use of technology in the teaching of motor skills has to a great extent attracted researchers' interest recently (Sorrentino, 2000). Furthermore, many researchers are experimenting with the development and application of audio and visual teaching tools, digital multimedia, and virtual learning environments for teaching motor skills (Antoniou et al., 2003; Vernadakis et al., 2002; Goulimaris et al., 2008; Kavakli et al., 2004; Smith-Autard, 2003; Popat, 2002; Parrish, 2000; Calvert, 2005).

It has been argued that the proposed multimedia learning environment, combining electronically supported images, sound, text and graphics with live performances, provide opportunities for personalized instruction, cooperation, feedback and creative interaction between the medium and the user. Their text may be in a written form (i.e., text on a computer screen), or in audio form (i.e., narration), while their images may be static (i.e., photographs, graphs, symbols, or maps) or dynamic (i.e., video, interactive depictions, or animation) (Mayer \& Moreno, 2003).

Although CAI has been used for more than 50 years, there is limited research on the effectiveness of CAI. In fact, several research studies have found no effects of CAI on certain subject matters. Overall, research on the effectiveness of CAI has produced inconsistent results.

Because ballet skills are complex and difficult, in education one needs clear effort to reach the learner to the point of perfection. As ballet dancers are known to engage in specific equilibrium exercises, their expert levels of postural stability are responsible for some impressive movements in choreography, such as when a dancer performs a balanced pose and holds the position for seconds (Paula et al., 2012).

Studies on the uses of technology in the field of learning ballet skills are still few. Researchers believe that to enhance traditional teaching methods with modern technological means may contribute to raising the learner's efficiency and ability to interact during the course of a lesson. It provides an instructional interaction between the learner and the computer in a variety of contexts with or without the assistance of a teacher (Lockard \& Many, 1997).

Therefore, the purpose of this study was to investigate whether or not multimedia technology affected learning basic ballet skills. 


\section{Methods}

\section{Participants}

A total of 32 undergraduate female, mean age 18.1 years, from the Faculty of Physical Education Zagazig University were divided into two equal groups. The experimental group comprised 16 students. The subjects in this group participated in a ballet class with multimedia technology for six weeks. Group two participated in the ballet class with a traditional method (teacher instruction) as the control group. Parameters assessed the height, weight, age, and academic level. All participants were beginners (had not practiced ballet before). All subjects were free of any disorders known to affect performance, such as bone fractures, osteoporosis, diabetes, or cardiovascular disease. The participants reported no use of anti-seizure drugs or alcohol. Participants were fully informed about the aims of the study, and gave their voluntary consent prior to participation. The measurement procedures were in accordance with the ethical human experimentation.

\section{Procedures}

The experimental group completed a 45-minute instruction session about teaching ballet skills (pas echappe (Step of escaped), pas de bouree (Step of Bourrée) and pas de chat (Step of the cat). For this group, a professor assisted students as a facilitator in the computer laboratory. CAI assists learners by presenting material and acting as a tutor. CAI uses computers to facilitate student learning. Students interact with computers at their own pace, and the responsibility of the teacher becomes that of a facilitator or coach. One of the major roles of CAI is to direct students' attention to different sections in a learning sequence without the assistance of a teacher. The first CAI program, Interactive Ballet, is computer software that provides a comprehensive approach to teaching ballet. This program is a computer tutorial that includes information and quizzes on equipment, rules, strokes, etiquette, and strategies as well as videos of top professionals explaining and demonstrating the basic steps in ballet. A researcher designed Interactive Ballet as a tutorial.

The second CAI program, Ballet Task Analysis, is a problem-solving program that promotes the development of observation skills of physical education students and teachers. It was designed to improve basic skills of ballet analysis by using concept mapping, restructuring tasks, and videos.

The Teacher Instruction group (TI) received a 45-minute teacher instruction session from a main investigator about teaching ballet skills as a comprehensive teaching method including demonstration, discussion, and drill.

\section{Knowledge Test of Ballet basic skills}

Knowledge test (KT) is special subject-matter knowledge that provides information about the content to be learned. A 14-item multiple-choice test was developed by the main investigator to measure basic ballet skills content knowledge. The purpose of this test was to measure knowledge of the five phases of basic ballet skills: ready phase, leg phase, swing phase, arm phase, and final phase.

\section{Statistical analysis}

All statistical analyses were calculated by the SPSS statistical package. The results are reported as means and standard deviations (SD). Differences between the two groups were reported as a mean difference of $\pm 95 \%$ confidence intervals (mean difference $\pm 95 \% \mathrm{CI}$ ). The Student's t-test for independent samples was used to determine the differences in fitness parameters between the two groups. The result $\mathrm{p}<0.05$ was considered statistically significant. 


\section{Results}

Table 2. Mean $\pm \mathrm{SD}$ and the "T" sign between two groups (experimental and control) in the Step of escaped, the Step of Bourrée, the Step of the cat, and Knowledge test

\begin{tabular}{|c|c|c|c|c|c|c|c|}
\hline \multirow{2}{*}{ Variables } & \multicolumn{2}{|c|}{ Experimental group } & \multirow{2}{*}{$\begin{array}{l}\text { improvement } \\
\text { Rate }\end{array}$} & \multicolumn{2}{|c|}{ Control group } & \multirow{2}{*}{$\begin{array}{l}\text { improvement } \\
\text { Rate }\end{array}$} & \multirow{2}{*}{$\begin{array}{l}\mathrm{T} \\
\text { sign. }\end{array}$} \\
\hline & Pre & Post & & Pre & Post & & \\
\hline $\begin{array}{l}\text { Step of escaped } \\
\text { (degree) }\end{array}$ & $0.8 \pm 0.07$ & $2.93 \pm 0.53 *$ & 266.25 & $0.6 \pm 0.03$ & $1.55 \pm 0.53 *$ & 158.33 & Sign. \\
\hline $\begin{array}{l}\text { Step of Bourrée } \\
\text { (Degree) }\end{array}$ & $0.9 \pm 0.02$ & $3.00 \pm 0.60 *$ & 233.33 & $0.8 \pm 0.07$ & $2.03 \pm 0.54^{*}$ & 153.75 & Sign. \\
\hline $\begin{array}{l}\text { Step of the cat } \\
\text { (Degree) }\end{array}$ & $0.5 \pm 0.01$ & $\begin{array}{l}3.17 \\
\pm 0.41^{*}\end{array}$ & 534 & $0.7 \pm 0.01$ & $\begin{array}{l}2.11 \\
\pm 0.73 *\end{array}$ & 201.43 & Sign. \\
\hline $\begin{array}{l}\text { Knowledge test } \\
\text { (Degree) }\end{array}$ & $5.75 \pm 0.91$ & $\begin{array}{l}9.42 \\
\pm 0.40^{*}\end{array}$ & 63.83 & $5.06 \pm 0.98$ & $\begin{array}{l}5.68 \\
\pm 0.67^{*}\end{array}$ & 12.25 & Sign. \\
\hline
\end{tabular}

Table 2 shows that significant differences were found among the groups in Step of escaped, Step of Bourrée, the step of the cat, and the Knowledge test.

Significant improvements were found among the groups in Step of escaped, Step of Bourrée, the step of the cat, and the Knowledge test.

\section{Discussion and conclusion}

Based on the results of this study, the t-test showed statistically significant differences between the post measurements of the experimental group in all basic ballet skills.

The researcher believed that this improvement attributed to the Multimedia Computer-assisted Instruction (MCAI), as the quality of a learning tool is not only measured with the capacity of deployment, but the tool's ability to interact with learners and meet their various needs. Participants with the multimedia program could analyze and correct the errors in the skills performance. One of the most common ways to do this is the qualitative analysis of movement, which has been defined as observing a movement and deciding how closely the specific features and sequence patterns of the performance adhere to accepted standards for that specific skill (Morrison \& Reeve, 1988). According to Shaoyan and Yunjian (2012), multimedia technology improves the quality of physical teaching and effects many with various functions. Its lively language and vivid pictures can arouse student attention and stimulate student interest, which is opposite to stiff traditional teaching. Moreover, multimedia technology can expand students' thinking and improve their ability to put forward, analyze, and finish problems. College physical teaching becomes easier because multimedia technology can slow, freeze, and magnify videos and pictures, which make it simple to explain highly difficult and new learning actions with exact action presentation.

On the other hand, task sequence is an essential part of skill analysis. Teachers follow these teaching patterns when they teach skills in a sequential order. Skill analysis is an important and vital capacity for every physical education teacher to have because physical education teachers must know the critical features of a skill or movement and to provide immediate feedback. Skill analysis may lead to the early detection of errors; corrective feedback can assist in skill development. 
Nowadays, the wide use of multimedia technology in college physical education alters traditional teaching methods, improves teaching effect, and makes teaching procedure vivid (Shaoyan \& Yunjian, 2012).

Research has demonstrated that subjects who participate in special training in skill analysis performed significantly better in the detection of errors compared to other participants who did not have training (Morrison \& Reeve, 1988; Satern et al., 1992).

However, it should be noted that this was one of the first studies that utilized multimedia CD-ROMs in teaching skills and task analysis in the field of ballet sport. Previous research studies used different methods of qualitative skill analysis training, such as written texts (Kernodle \& McKethan, 2002), interactive videodisc (Walkley \& Kelly, 1989), and videotape (Morrison \& Reeve, 1988).

Siedentop (1988) stated that completion performed significantly better than the CAI and CG groups. Finally, the experimental and control groups improved significantly within the group from pre- to post-test

In brief, Multimedia technology can transmit more data of higher quality than traditional mediums in unit time and limited area. In addition, it's possible to dispose of and express much data, including both pictures and words. This offers students the convenience to conceive words, data, and understand teaching objects. Because of the rapid and efficient disposal of words, sounds, pictures, cartoons and their simulation, multimedia technology makes teaching more vivid and direct, which is not caught by the traditional medium.

Students' perceptions of CAI and computers have become an important concept, as computers are a common part of today's schools in all grades. Although research in general education courses produced different results about students' attitudes toward CAI (Fratianni et al., 1990; Kraus et al., 1994), research in physical education found that students had positive attitudes toward CAI and expressed their willingness to use CAI in future activities as a learning tool (Alvarez-Pons, 1992; Wilkinson et al., 1999).

In conclusion, multimedia technology can produce and dispose of words, language, pictures, and video better with speedy expression and a rich network resource, which favors knowledge renovation.

\section{REFERENCES}

Alvarez-Pons, F. A. (1992). The effectiveness of computer assisted instruction in teaching sport rules, scoring procedures, and terminology. Unpublished doctoral dissertation, College of Education, Florida State University.

Antoniou, P., Derri, V., Kioumourtzoglou, E., \& Mouroutsos, E. (2003). Applying multimedia computer assisted instruction to enhance physical education students' knowledge of basketball rules. European Journal of Physical Education, 8, 78-90.

Bull, G., Harris, J., \& Loyd, J., \& Short, J. (1989). The electronic academic village. Journal of Teacher Education, 40 (4), 27-31.

Calvert, T., Wilke, L., Ryman, R., \& Fox, I. (2005). Applications of computers to dance. IEEE Computer Graphics and Applications, 6-10.

Fratianni, J., Decker, R., \& Korver-Baum, B. (1990). Technology: Are future teachers being prepared for the 21st century? Journal of Computing in Teacher Education, 6 (4), 15-23.

Goulimaris, D., Koutsouba, M., \& Giosos, Y. (2008). Organisation of a distance postgraduate dance programme and the participation of students specializing in dance. Turkish Online Journal of Distance Education, 9, 3, 59-73.

Harris, J., \& Anderson, S. (1991). Cultivating teacher telecommunications networks from the grass roots up: The electronic academic village at Virginia. Computers in Schools, 8 (1/2/3), 191-202.

Kavakli, E., Bakogianni, S., Damianakis, A., Lamou, M., \& Tsatsos, D. (2004). Traditional dance and e-learning: The Web Dance learning environment. http://www.aegear.gr/culturaltec/webdance/publications.htm (accessed: 20 November, 2010).

Kernodle, M., \& McKethan, R. (2002). The effects of a computer-based distance learning program on qualitative sill analysis by preservice physical education teachers and preservice elementary education teachers. Paper presented at AAHPERD National Convention, (San Diego, CA).

Kraus, L. A., Hoffman, N., Oughton, J. M. (1994). Student teachers' perceptions of technology in the schools. In J. Willis, B. Robin, \& D. Willis (Eds.), Technology and teacher education annual-1994. (pp. 42-45). Charlottesville, VA: Association for the Advancement of Computing in Education. 
Lockard, J., Abrams, D. P., \& Many, W. A. (1997). Microcomputers for twenty-first century educators (4 ${ }^{\text {th }}$ ed.). New York, NY: Longman.

Mayer, R. E. \& Moreno, R. (2003). Nine ways to reduce cognitive load in multimedia learning. Educational Psychologist, 38, 43-52.

McKethan, R., Everhart, B., \& Sanders, R. (2001). The effects of multimedia software instruction and lecture-based instruction on learning and teaching cues of manipulative skills on preservice physical education teachers. The Physical Educator, 58 (1), 2-13.

Morrison, C. S., \& Reeve, E. J. (1988). Effect of instruction and undergraduate major on qualitative skill analysis. Journal of Human Movement Studies, 15, 291-297.

Morrison, C. S., \& Reeve, E. J. (1992). Perceptual style and instruction in the acquisition of qualitative analysis of movement by majors in elementary education. Perceptual and Motor Skills, 74, 583-597.

Parrish, M. (2000). Integrating technology into the teaching and learning of dance. Journal for the National Dance Education Organization, 1,1, 20-25.

Paula H. Lobo da Costa, Fernanda G. S. Azevedo Nora, Marcus Fraga Vieira, Kerstin Bosch , Dieter Rosenbaum (2012). Single leg balancing in ballet: Effects of shoe conditions and poses. Gait \& Posture, In Press, Corrected Proof, Available online 16 September 2012.

Popat, S. (2001). Interactive dance-making: online creative collaborations. Digital Creativity, 12, 4, $205-214$.

Satern, M. N., \& Coleman, M. M., \& Matsakis, M. H. (1991). The effect of observational training on the frequency of skill-related feedback given by preservice teachers during two peer teaching experiences, KAHPERD Journal, 60 (2), 12-16.

Siedentop, D. (1988). Skill analysis: Prerequisite for effective feedback. Proceedings of Seoul Olympic Congress. (pp. 247-251), Seoul, Korea.

Smith-Autard, J. (2003). The essential relationship between pedagogy and technology in enhancing the teaching of dance form. Research in Dance Education, 4, 2, 147-165.

Sorrentino, R. (2000). A Simulation of Internet Enhanced Motor Learning. Ph.D. thesis, University of Calgary, Canada.

Vernadakis, N., Zetou, E., Antoniou, P., \& Kioumourtzoglou, E. (2002). The effectiveness of computer assisted instruction in teaching the skill of setting in volleyball. Journal of Human Movement Studies, 43, 151-164.

Waggoner, M. (1992). Planning for the use of computer conferencing in collaborative learning. In D. Carey, R. Carey, D. Willis, \& J. Willis, (Eds.), Technology and Teacher Education Annual-1992 (pp. 556-561). Charlottesville, VA: Association for the Advancement of Computing in Education

Walkley, J. W., \& Kelly, L. E. (1989). The effectiveness of an interactive videodisc qualitative assessment training program. Research Quarterly for Exercise and Sports, 60 (3), 280-285.

Wilkinson, C., Hillier, R., Padfield, G., \& Harrison, J. (1999). The effects of volleyball software on female junior high school students' volleyball performance. The Physical Educator, (4), 202-209.

AUTHOR'S ADDRESS:

\author{
Doaa Abb El-Moneim \\ Zagazig University \\ Faculty of physical education for girls \\ Zagazig, Sharkia \\ Egypt \\ Email: dmoneim_2012@yahoo.com
}

